\title{
Evolution of depositional systems and sedimentary cycles in Želiezovce Depression of the Danube Basin
}

\author{
Samuel Rybár ${ }^{1}$, Katarína Šarinová ${ }^{2}$ Michal Šujan ${ }^{1}$, Eva Halásová ${ }^{1}$ \\ Natália Hudáčková ${ }^{1}$, Adriena Zlinska ${ }^{3}$, Michal Kováč ${ }^{1}$, Marianna \\ Kováčová ${ }^{1}$, Andrej Ruman $^{1}$, Lucia Ledvényiová ${ }^{1}$
}

${ }^{1}$ Comenius University in Bratislava, Faculty of Natural Sciences, Department of Geology and Paleontology;
Mlynská dolina G, 84215 Bratislava, Slovakia; e-mail: samuelrybar3@gmail.com
${ }^{2}$ Comenius University in Bratislava, Faculty of Natural Sciences, Department of Mineralogy and Petrology;
Mlynská dolina G, 84215 Bratislava, Slovakia
${ }^{3}$ State Geological Survey of Dionýz Śtúr; Mlynská dolina, 181704 Bratislava, Slovakia

(C) 2015 Authors. This is an open access publication, which can be used, distributed and reproduced in any medium according to the Creative Commons CC-BY 4.0 License requiring that the original work has been properly cited.

Five deep wells (Pozba4, Pozba3, Dubnik1, Nová Vieska1, Modranyl), drilled in the Želiezovce depression of the south-east Danube Basin penetrate the Cenozoic sedimentary record in overall thickness ranging from $1000 \mathrm{~m}$ up to $3000 \mathrm{~m}$. The total thickness gradually increases from South to the North. This area is well known for the complex geological structure related to the Central Western Carpathians and Transdanubian Range junction along the Hurbanovo - Diösjenö line. Many authors have studied this area in the past, nevertheless depositional systems, sedimentary cycles and the development of sedimentary facies were never understood in detail. The re-evaluation of biostratigraphy, paleoecology, sedimentology and the re-interpretation of e-logs were all incorporated into well correlations, what resulted in definition of four main sedimentary cycles: (1) the lowermost Oligocene cycle, consisting of mudstones with occasional sandstone intercalations, associated with slope to offshore marine environment. The age is supported by the presence of the NP 22 calcareous nannoplankton zone; (2) the transgressive Langhian (Lower Badenian) deposits, composed of mudstones with epiclastic volcanic material and tuffite beds were associated with nearshore to offshore environement. The age is supported by the NN4-NN5 calcareous nannoplankton zone;
(3) the Serravallian (Upper Badenian-Sarmatian) cycle is composed mainly of mudstones with abundant Lithothamnium fragments associated with brackish, coastal pain environment. The age is confirmed by the NN6 calcareous nannoplankton zone and by the mass occurrence of fish scales and Ervilia dissita (Eichwald) bivalves; (4) the overlying strata represent the Tortonian-Pliocene (Pannonian-Pliocene) cycle. The strata consist mostly from claystone (lake environment) which is overlain by sandstone and siltstone layers (deltaic and alluvial plain environments). The Tortonian (Pannonian) age of the lowermost claystone is supported by finds of Dreissenidae bivalves. The Pliocene age is only inferred by superposition of the strata.

This work was supported by the research grants APVV-0099-11, APVV-0625-11 and Grant UK/325/ 2014. We also express gratitude to APVV LPP 0120-06, ESF-EC-0006-07, ESF-EC-0009-07 and VEGA 2/0042/12. Additionally our acknowledgements go to Dr. L. Sliva from Nafta as. for grating access to well repositories, to Dr. O. Mandic for the Nature History Museum in Vienna and to Doc. Katrína Holcová from the Charles University in Prague for biostratigraphical consulting. Our special thank you goes to Š. Pramuková and M. Hronkovič for help with well core martial and thin section assembly. 